\title{
Supply Chain Management and Organization Performance: A Value Creation Perspective
}

\author{
Evans Kyeremeh \\ School of Business, \\ University of Education, Winneba, Ghana \\ Mawuko Dza \\ School of Business, \\ University of Education, Winneba, Ghana
}

\begin{abstract}
The purpose of the study is to investigate how manufacturing firms in Ghana create value along the supply chain by integrating their unique skill-sets and building strong relationships among partners of the chain. The key objective is to examine how strategic supply chain management practices improve organisations performance. Data were collected and analyzed using exploratory factor analysis, correlation, regression analysis and other analytic techniques. The findings revealed that although supply chain management practices have some level of impact on supply chain performance, the effect is less influenced by value creation. With a $\beta=.568 ; t=5.316$, the implication is that there is about $53 \%$ change in supply chain performance when a single value is created. However, value creation does not perfectly moderate supply chain management practices. Additionally, the study shows that value creation influences information and technology management to significantly contribute negatively on supply chain performance by about $26 \%(\beta=-0.26 ; t=-2.226)$. It is therefore imperative for practitioners in the manufacturing sector to identify key supply chain management practices, which greatly impact on supply chain performance in order to optimize production.
\end{abstract}

Keywords: Strategic supply chain management, value creation, customer, manufacturing

\section{INTRODUCTION}

Supply chain management (SCM) is one of the mechanisms that manufacturing companies adopt to enjoy competitive advantage over their competitors. It encompasses the planning and management of all activities involved in sourcing and procurement; conversion; and all logistics management activities (Xi \& Canhua, 2008). In the past decades, businesses have witnessed lots of unprecedented changes as a result of current dynamics of the global business environment. The most remarkable change is that the markets have evolved into an era of integration and networking. The implication being that, businesses no longer compete as autonomous entities, but through supply chains. Today, customer value is placed on the top of SCM academics' research agendas and at the core of business marketing strategies. Customers are perceived as a key source of competitive advantage in organizations. Revenue enhancement, suppliers gaining products ideas, technologies, access to information or market access from their customers have made it imperative for firms to maintain high customer levels while at the same time reducing cost and increasing profit margins. Thus, customers and value delivered to them have become the centre of companies' strategies (Kristensen \& Górecka, 2008). This study primarily focuses on supply chain performance and how it can be enhanced along the value creation process of manufacturing companies. 
According to Drucker (2012), the purpose of any business is to create and maintain satisfied customers. A company can earn profits only if it creates value in its products and deliver same to its customers. Customer value is the understanding of customer's desire and aligning internal resources to respond to those needs effectively and efficiently (Christiansen, 2015). To deliver customer value, organizations need to focus on innovation, quality of products and services, ensure optimal utilization of available resources, harness the skills sets of employees and provide the requisite infrastructure to create value. In general, customer value is a combination of the company's image, quality of products or services, and the price at which the product is available. With current customer sophistication, assuring customer satisfaction demands the most visible and flexible supply chain. Customers acquiring, possessing and using products and services at lowest cost is all-important to a visible, flexible and efficient supply chain.

For sometime now, researchers of SCM as well as the public have been interested in published research relating to improving cost efficiency; optimizing the SC; efficiently controlling production; properly managing stock levels; and practice SC integration. It is significant to learn that, despite researcher interest in the study area, there are few known studies that sought to explore how SC performance is predicted by SCM practices vis-à-vis value creation especially in manufacturing companies in Ghana. This study therefore bridges the gap in knowledge and adds to the extant literature by unravelling how manufacturing companies in Ghana enhance the creation of customer value along the SC by integrating their unique skillsets, information and technology among others to build strong relationships among partners in order to increase productivity, reduce cost and increase profit margins for partners of the chain.

\section{SUPPLY CHAIN MANAGEMENT AND VALUE CREATION}

SCM is that aspect of management that controls and coordinates activities of organizations from the upstream through the midstream to the downstream (Kristensen \& Górecka, 2008). The primary objective of SCM is to integrate and manage the sourcing, flow, and control of materials using a total systems perspective across multiple functions and multiple tiers of suppliers (Monczka, et al., 1998). Contemporarily, SCM has shifted focus from production efficiency to customer-driven and partnership synchronization approaches (Jain et al., 2009) with the objective to optimize the order fulfillment process (Tan et al., 2000). It is important that supply chains maximizes the overall value generated, because sticking to a portion of the chain not only makes no commitment to maximizing overall chain profit but also reduces the whole SC profitability (Heydari, et al., 2009), thus creating and delivering value to the customer and in turn creating sustainable value for all its stakeholders.

\section{INTERNAL AND EXTERNAL VALUE}

The goal of businesses is to make profit by delivering value to customers at competitive costs (Wilding, 1998). As organizations form part of supply chains, value becomes more complex and assumes multidimensional characteristics (Kerr \& Ulrich, 1995). In this context, internal and external value becomes important (Bititci et al., 2004). Internal value or shareholder value refers to the increase of profits that supports the business financial objectives and continuous growth of SC partners. According to Schnetzler, et al., (2007), when the strategic priorities of SC partners are translated into SC objectives, they can be implemented as SC operations. Kampstr et al., (2006) suggests that, in order to smoothen SC operations and act according to the chosen SC strategy, it must be decided that the right capacities and inventories are properly positioned. Truong \& Azadivar, (2005) also suggest that these capacities and inventories form the SC structure, which needs to be optimized in order to achieve high level of 
SC performance. Sharifi et al., (2006) relate the creation of internal value to the SC design, which focuses on the design of the SC strategy, structure, processes, operations, and management elements to achieve the market objectives. External value on the otherhand provides high quality products that meet customer needs of price, service, and image (Martínez-Olvera, 2015). Christopher, et al., (2006) explain that the success or failure of the SC is ultimately determined at the marketplace by the end consumer. Terzi and Cavalieri, (2004) also point out that the service provided to the end customer is determined by the effectiveness and efficiency of the cooperation of all the partners within the SC. Therefore, in this customeroriented context, the SC as a whole must focus on providing the customer with what they want, how they want it, where they want it, and when they want it (Zhang, et al, 2008).

\section{VALUE CONSTRUCT}

In recent years, there has been a resurgence of interest in the value construct among both practitioners and marketing researchers (Ulaga, 2001). This has been triggered by the belief that managing companies from value-based perspective will increase the likelihood of gaining competitive advantage and long-term success (Kristensen \& Górecka, 2008). Previous research also provides empirical support for adopting a customer value approach. According to Fredericks et al, (2001) an increase in customer loyalty leads to better business performance. Despite increasing attention on the customer value concept, researchers are not reaching an agreement about how to define these construct (Woodruff, 1995). The lack of understanding of the customer value domain relates not only to defining the constructs but also on how to make them operational (Parasuraman, 1997). Two ways of operationalizing customer value are prominent. The first framework is rooted in customer equity and customer lifetime value (Rust et al., 2004) while the second relates to practitioners and consultants, and is related to customer value added (Gale, 1994). The difference between these two resides in the way they conceptualize customer value construct: as a rational trade-off or as a combination of a rational and an emotional trade-off.

\section{SUPPLY CHAIN PARADIGM AND COOPERATION}

Over the past three decades or so, the corporate environment has experienced extreme unrest and turbulence. According to Park et al., (2010) globalization of markets, changes in customer needs, and the complex nature of product components, efficiency of supply chains have become a crucial factor in organizations' competitiveness. Many companies have responded by adopting organizational configurations such as alliances, networks and supply chains which today represents central organizational units in industries (Duclos et al., 2003). At present, two paradigms drive SCM approaches - a cooperative paradigm and a competitive paradigm. The concept of competition is built on the assumption reflecting the ideas of Adam Smith, according to which individuals act to maximize their own benefit. The main implication of the competitive paradigm is that the inter-firm interdependences define a zero-sum game structure (Padula and Dagnino, 2007). This means that the profit of one actor increases the loss of another actor. According to Lydeka and Adomavicius (2007), companies gain competitive advantage in two ways - first, by achieving an advantageous position in an industry and by developing and using core competences to offer better products and services. Competition is a useful and allowed strategy for all parties of the supply chain; upstream, midstream and downstream activities. Value creation is also connected with cooperation in many other perspectives adopted in the field of management studies such as; co-evolution, cocreation or role of producers and consumers. Lamberg and Laurila (2005) opine that the focus is on the long-term beneficial cooperation and evolution between firms. These two are complementary and can be simultaneously brought together to form a third paradigm called co-opetition (Duclos et al., 2003). Coopetition is a relatively new concept that emphasizes simultaneous competition and cooperation between firms. The root of the word coopetition 
comes from the words 'cooperation' and 'competition' (Luo et al., 2006). Coopetition is not such a paradigm like cooperation or competition, but it is possibly a complementary paradigm (Bengtsson et al., 2010).

\section{SUPPLY CHAIN MANAGEMENT PRACTICES, PERFORMANCE AND VALUE CREATION}

There have been quite a number of studies on SCM practices, performance and value creation (Abdallah et al., 2014; Sukati et al., 2006; Li et al., 2006). In spite of the fact that all these studies adopt different approaches, they all come to a conclusion that SCM practices have effect on SC performance. For instance, Abdallah et al., (2014) indicated that supply chain practices of internal integration, information sharing and postponement, significantly and positively affect supply chain efficiency as well as performance. Similarly, Li et al., (2006) indicate that higher levels of SCM practices can lead to enhanced competitive advantage and improved organizational performance. Indeed, supply chain practices have a significant relationship with SCM performance as opined by Sukati et al., (2012). However, they also indicated that supply chain strategy is rather a weaker predictor of SCM performance. There are continuing arguments and debate on how SC performance could be effectively measured (Akyuz and Erkan, 2010). Other studies indicate that the success of supply chains is dependent on the value it creates for customers and customers value is mostly measured by the product value to them; standards set by the customer; understanding customer needs; retention of loyal customers and alignment of organizations goals in terms of customer needs (Fecikova, 2004).

\section{RESEARCH APPROACH}

The target population for the study is based on SC practitioners in manufacturing companies within the Kumasi Metropolitan Assembly of Ghana. A total of one hundred (100) respondents who constitute the sample size were purposively selected and were served with the questionnaires. Responses from practitioners were analyzed using appropriate analytic techniques. The study also assessed the suitability of the items used in measuring the constructs through the use of a reliability test using Cronbach Alpha and performing validity test using exploratory factor analysis (EFA).

\section{RELIABILITY OF THE MEASURES}

In checking for reliability of the measures, Cronbach alpha was used to verify the internal consistency among the measures (Pallant, 2007). This was performed with SPSS version IBM 20 . The results shown in table 1 , indicate that alpha values ranges from 0.628 to 0.841 . This implies that the items used in measuring Order Process Management failed. Apart from that, all items for the seven other constructs passed the initial test of reliability as they were far above the recommended threshold of 0.70 . The summary of results could be seen from Table 1 .

Table 1: Reliability Test Results

\begin{tabular}{|c|c|c|}
\hline Construct & Number of items & Alpha value \\
\hline 1. Demand Management & 5 & 0.830 \\
\hline 2. Capacity Resource Management & 8 & 0.769 \\
\hline $\begin{array}{l}\text { 3. Customer Relationship } \\
\text { Management }\end{array}$ & 7 & 0.834 \\
\hline 4. Order Process Management & 5 & 0.628 \\
\hline $\begin{array}{l}\text { 5. Service Performance } \\
\text { Management }\end{array}$ & 7 & 0.738 \\
\hline $\begin{array}{l}\text { 6. Information and Technology } \\
\text { Management }\end{array}$ & 7 & 0.771 \\
\hline 7. Value Creation & 9 & 0.814 \\
\hline 8. Supply Chain Performance & 10 & 0.841 \\
\hline
\end{tabular}




\section{MEASUREMENT OF VALIDITY}

Although the results from the reliability test shown in table 1.0 indicate that all the scales for their respective constructs had strong internal consistency, it became necessary to perform exploratory factor analysis (EFA) to help explore the interrelationships among and the dimensionality of constructs (Pallant, 2007). Hence, to demonstrate convergent validity, it was necessary to run EFA on each sub-construct. EFA was found more appropriate as the researchers developed some of the items and also the sample size of the study was not large enough to allow for confirmatory factor analysis (CFA). Using Principal Axis Factoring and Direct Oblimin with Kaiser Normalization for rotation, with Varimax rotation, seven factors were fixed to extract. In all the analyses, the system was set to extract components with values above 1.0 and also suppress coefficients with smaller loadings (thus, less than 0.50). The Kaiser-Meyer-Oklin value was 0.758, exceeding the recommended value of 0.6 and Bartlett's Test of Sphericity reached statistical significance, supporting the factorability of the correlation matrix (Pallant, 2007). Given a minimum loading of 0.50, the following items were retained. For DM, items retained were DM 1, 2, 3, 5, then for CaRM, items retained were CaRM 4-7, for CRM, items retained were CRM 1-5, 7-9 then for SPM, items retained were SPM 2,3,5,6 and then for ITM, items retained were ITM 1-3. However, for Value Creation (VC), items retained include VC 1, 3, 6 and then for Supply chain performance (SPC) items retained were SPC $1-4$. Items removed from each construct were those which could not load or had had cross-loadings with other components. After dropping the unwanted constructs and items, a satisfactory model was attained with each block of items loading onto its theoretically specified constructs. The remaining items after the EFA can be seen in Table $2 \mathrm{a}$ and Table $2 \mathrm{~b}$. 
Table 2a: Factor Loadings and Validity and Reliability Results from EFA

\begin{tabular}{|c|c|c|c|c|c|c|c|c|}
\hline \multirow[t]{4}{*}{ Constructs } & \multirow[t]{2}{*}{ Item } & \multirow[t]{2}{*}{ Details } & \multicolumn{6}{|c|}{ Component } \\
\hline & & & 1 & 3 & 4 & 5 & 6 & 7 \\
\hline & DM1 & The ability to simulate different demand needs. & 0.813 & & & & & \\
\hline & DM2 & Demand resources needs reliability & 0.770 & & & & & \\
\hline \multirow[t]{4}{*}{$\begin{array}{l}\text { Demand } \\
\text { Management }\end{array}$} & DM3 & $\begin{array}{l}\text { The ability to improve the accurate demand } \\
\text { forecasting and delivery by reconciling up to- } \\
\text { date information. }\end{array}$ & 0.760 & & & & & \\
\hline & DM5 & $\begin{array}{l}\text { The ability to match service capacity with } \\
\text { demand through operations }\end{array}$ & 0.730 & & & & & \\
\hline & CARM4 & $\begin{array}{l}\text { Have the tracking system in order to find the } \\
\text { problems of unused service capacity. }\end{array}$ & & & & 0.798 & & \\
\hline & & Service capacity utilization is low enough to & & & & & & \\
\hline \multirow{5}{*}{$\begin{array}{l}\text { Capacity and } \\
\text { Resource } \\
\text { Management }\end{array}$} & CARM5 & $\begin{array}{l}\text { provide near instant service or least waiting } \\
\text { time. }\end{array}$ & & & & 0.684 & & \\
\hline & CARM6 & $\begin{array}{l}\text { The ability to match service capacity with } \\
\text { uncertain demand. }\end{array}$ & & & & 0.754 & & \\
\hline & CARM7 & $\begin{array}{l}\text { The ability to adjust service capacity during } \\
\text { high and low demand. }\end{array}$ & & & & 0.746 & & \\
\hline & CRM1 & $\begin{array}{l}\text { The ability to develop long-term relationships } \\
\text { with customers. }\end{array}$ & & 0.800 & & & & \\
\hline & CRM2 & $\begin{array}{l}\text { Focus on customer satisfactions as the center of } \\
\text { corporate activities. }\end{array}$ & & 0.693 & & & & \\
\hline \multirow{4}{*}{$\begin{array}{l}\text { Customer } \\
\text { Relationship } \\
\text { Management }\end{array}$} & CRM3 & $\begin{array}{l}\text { The ability to communicate optimistic } \\
\text { information to customers. }\end{array}$ & & 0.787 & & & & \\
\hline & CRM4 & $\begin{array}{l}\text { The ability to establish effective relationships } \\
\text { with customers to the benefit of the brand } \\
\text { loyalty. }\end{array}$ & & 0.666 & & & & \\
\hline & CRM5 & $\begin{array}{l}\text { The ability to classify and prioritize key } \\
\text { customers. }\end{array}$ & & 0.615 & & & & \\
\hline & SPM2 & $\begin{array}{l}\text { Employees in organizations recognize the } \\
\text { benefits of service performance management. }\end{array}$ & & & 0.815 & & & \\
\hline \multirow{3}{*}{$\begin{array}{l}\text { Service } \\
\text { Capacity } \\
\text { Management }\end{array}$} & SPM3 & $\begin{array}{l}\text { Have a commitment to ensure accurate and } \\
\text { reliable service performance. }\end{array}$ & & & 0.839 & & & \\
\hline & SPM5 & $\begin{array}{l}\text { Employees have knowledge and skills in } \\
\text { working with integrity and confidence. }\end{array}$ & & & 0.790 & & & \\
\hline & SPM6 & $\begin{array}{l}\text { Employees are able to develop their personality } \\
\text { and refine their service performance. }\end{array}$ & & & 0.577 & & & \\
\hline \multirow{3}{*}{$\begin{array}{l}\text { Information } \\
\text { and } \\
\text { Technology } \\
\text { Management }\end{array}$} & ITM1 & $\begin{array}{l}\text { Using new technology for increased } \\
\text { channel/service points to customers to contact } \\
\text { the organization. }\end{array}$ & & & & & 0.716 & \\
\hline & ITM2 & $\begin{array}{l}\text { The ability to access information quickly any } \\
\text { time via information technology. }\end{array}$ & & & & & 0.719 & \\
\hline & ITM3 & $\begin{array}{l}\text { The ability to create effective networks } \\
\text { management to share information among } \\
\text { internal functions, suppliers and customers. }\end{array}$ & & & & & 0.808 & \\
\hline
\end{tabular}


Table 2b: Factor Loadings and Validity and Reliability Results from EFA

\begin{tabular}{|c|c|c|c|c|c|c|c|c|c|}
\hline \multirow[t]{2}{*}{ Constructs } & \multirow[t]{2}{*}{ Item } & \multirow[t]{2}{*}{ Details } & \multicolumn{7}{|c|}{ Component } \\
\hline & & & 1 & 2 & 3 & 4 & 5 & 6 & 7 \\
\hline Value & VC1 & $\begin{array}{l}\text { Reducing operational cost and achieving } \\
\text { customer satisfaction (ROC and ACS) }\end{array}$ & & & & & & & 0.741 \\
\hline Creation & VC3 & Knowledge accumulation (KA) & & & & & & & 0.633 \\
\hline & VC6 & Management Satisfaction (MS) & & & & & & & 0.551 \\
\hline & SCP1 & Organizational goals and objectives & 0.823 & & & & & & \\
\hline Sunply & & Visibility of links between & & & & & & & \\
\hline $\begin{array}{l}\text { Suppry } \\
\text { Chain }\end{array}$ & SCP2 & $\begin{array}{l}\text { organizational and supply chain } \\
\text { performance }\end{array}$ & 0.818 & & & & & & \\
\hline Performance & SCP3 & Level of trust between organizations & 0.729 & & & & & & \\
\hline & SCP4 & Organizational strategies & 0.698 & & & & & & \\
\hline Eigenvalues & & & 7.396 & 2.618 & 2.145 & 2.030 & 1.928 & 1.320 & 1.057 \\
\hline$\%$ of & & & 27.394 & 9.696 & 7.943 & 7.517 & 7.142 & 4.889 & 3.916 \\
\hline Variance & & & & & & & & & \\
\hline Cronbach $\alpha$ & & & 0.848 & 0.830 & 0.826 & 0.804 & 0.745 & 0.759 & 0.662 \\
\hline КМO & & $=0.758$ & & & & & & & \\
\hline $\begin{array}{l}\text { Bartlett's } \\
\text { test of } \\
\text { Spherity: }\end{array}$ & & $=x^{2}(D F)=1666.899(231) ; p=0.000$ & & & & & & & \\
\hline
\end{tabular}

Notes:

1. Extraction Method: Principal Axis Factoring.

2. Rotation Method: Varimax with Kaiser Normalization.

3. Rotation converged in 7 iterations.

\section{Test of Model}

In establishing the effect of value creation on strategic SCM and SC performance, correlation and regression analysis were employed. Five main independent variables were considered representing SCM practices - Demand Management (D), Capacity and Resource Management (C); Customer Relations Management (M), Service Capacity Management (S) and Information and Technology Management (T), while the dependent variable was SC Performance (P) with Value Creation (V) as a Moderating Variable. Supplier Relationship Management (R) and Product and Service Quality (Q).

The regression estimates were given as:

$$
Q=b_{0}+b_{1} D+b_{2} C+b_{3} M+b_{4} S+b_{5} T+b_{6} D V+b_{7} C V+b_{8} M V+b_{9} S V+b_{10} T V+
$$

Where

$b_{0}=$ cons $\tan t$ of proportionality

$b_{1}=$ coefficient of DM independent variable

$b_{2}=$ coefficient of CaRM independent variable

$b_{3}=$ coefficient of CRM independent variable

$b_{4}=$ coefficient of SPM independent variable

$b_{5}=$ coefficient of ITM independent variable

$b_{610}=$ coefficient of $V$ as moderator with independent variable 


\section{= error term \\ $S=$ Supply Chain Performance}

Table 3: Correlations of Variables and Descriptive Statistics

\begin{tabular}{|c|c|c|c|c|c|c|c|}
\hline Constructs & 1 & 2 & 3 & 4 & 5 & 6 & 7 \\
\hline 1. Demand Management & 1 & & & & & & \\
\hline 2. Capacity and Resource Management & .115 & 1 & & & & & \\
\hline 3. Customer Relationship Management & $.370^{* *}$ & .162 & 1 & & & & \\
\hline 4. Service Capacity Management & $.309^{* *}$ & .143 & $.390^{* *}$ & 1 & & & \\
\hline 5. Information and Technology Management & $.288^{*}$ & .209 & .214 & $.407^{* *}$ & 1 & & \\
\hline 6. Value Creation & $.448^{* *}$ & .156 & $.416^{* *}$ & $.300^{* *}$ & $.406^{* *}$ & 1 & \\
\hline 7. Supply Chain Performance & $.374^{* *}$ & -.001 & $.385^{* *}$ & $.319^{* *}$ & $.386^{* *}$ & $.528^{* *}$ & 1 \\
\hline Mean & 5.40 & 4.78 & 5.48 & 5.27 & 5.35 & 5.39 & 5.42 \\
\hline Standard Deviation & 0.925 & 0.956 & 0.837 & 0.905 & 0.825 & 0.796 & 0.856 \\
\hline
\end{tabular}

The correlation results shown in Table 3 above generally revealed that, actors in the manufacturing sector in the Kumasi Metropolis partly attribute their SC performance to their SC practices and value creation. Also, all SC practices have positive correlations with SC performance except capacity and resource management and were significant at 0.01 or 0.05 . However, their relationships are not strong since most of the coefficients $(\mathrm{r}$ ) are less than 0.5. Meanwhile, correlation between value creation and SC performance was positive and quite high (0.528) and significant at 0.05.

\section{Model Assessment}

From the reliability and validity test runs, some of the OPM construct did not pass and as such the research model had to be modified before regression analysis could be run. The model estimation process began with creating composite variables and interaction term and then examining relevant assumptions underlying the method of estimation employed in the study. Relying on each of the set of retained measures, arithmetic mean was used to create the composite variables. Five SC practices passed the reliability tests and were treated as composite variables by averaging their respective items remaining. Same was done with the value creation and product and SC performance variables. The researchers used ordinary least square regression analysis to estimate the study's new proposed model. The main outcome variable was SC performance and the main predictor variables were demand management, capacity and resource management, customer relationship management, service capacity management and information and technology management.

For Model 1, SC performance was being predicted by the SC management practices - demand management, capacity and resource management, customer relationship management, service capacity management and information and technology management. From the initial model, the practices included order processing management. However, that variable failed the reliability test and thus eliminated.

In the case of Model 2, SC performance was being predicted by the SC management practices demand management, capacity and resource management, customer relationship management, service capacity management and information and technology management and also the moderating effect of value creation on each independent variable. The results to these effect relationships could be seen from Table 4 


\section{Table 4: Ordinary Least Square Regression Estimates}

Variables:

Hypothesized

Direct Effect

Demand Management (DM)

Capacity and Resource Management (CaRM)

Customer Relationship Management (CRM)

Service Capacity Management (SPM)

Information and Technology Management (ITM)
Standard Estimates

Supply Chain Performance

Model 1

Model 2

$\begin{array}{cc}0.183(1.7568) & -0.048(-0.059) \\ -0.117(-1.2605) & -0.635(-1.151) \\ 0.253(2.1492) & 0.517(0.655) \\ 0.065(0.2799) & -1.403(-1.732) \\ 0.286(2.4214) & 1.499(2.454)\end{array}$

$0.568(5.316)$

$0.028(0.194)$

$0.092(0.930)$

$-0.076(-0.850)$

$0.296(1.850)$

$-0.26(-2.226)$

\section{FIT INDICES}

$\chi^{2}(\mathrm{df})$

$\chi^{2} / \mathrm{df}$

F-Statistics

$\mathrm{R}^{2}$

Durbin-Watson

Notes:

1. $t$-values are in the parenthesis

2. \pm represents significant $F$ value significant at $1 \%$

3. $* \&^{* *}$ represent significant path at 5\% (1-tailed test: 1.645$)$ and 1\% (1-tailed test: 2.33 ) respectively

4. Hypothesized paths evaluated at 5\% significance level (1-tailed test)

\section{HYPOTHESES AND TESTING}

H1: Supply Chain Management practices significantly and positively impact on supply chain performance among manufacturing companies in the Kumasi Metropolis of Ghana.

H2: Value Creation significantly and positively moderates with supply chain management practices to achieve supply chain performance.

The modified models and summary of the results of the hypotheses tested are displayed in Table 5.0.

\begin{tabular}{lll}
\hline Variables & Results & Remarks \\
\cline { 2 - 3 } $\begin{array}{l}\text { Dependent Variable: } \boldsymbol{S C P} \\
\text { Independent Variables: }\end{array}$ & & \\
DM & $\beta=0.183 ; \mathrm{t}=1.7568$ & $\begin{array}{l}\text { Positive effect, not significant } \\
\text { CaRM }\end{array}$ \\
CRM & $\beta=-0.117 ; \mathrm{t}=-1.2605$ & $\begin{array}{l}\text { Negative effect, not significant } \\
\text { SPM }\end{array}$ \\
ITM & $\beta=0.253 ; \mathrm{t}=2.1492$ & Positive effect, significant \\
& $\beta=0.065 ; \mathrm{t}=0.2799$ & Positive effect, not significant \\
& $\beta=0.286 ; \mathrm{t}=2.4214$ & Positive effect, significant
\end{tabular}
Positive effect, significant Positive effect, not significant Positive effect, not significant Negative effect, not significant Positive effect, not significant Negative effect, significant


From the initial proposed research model, six SC practices were developed to influence SC performance. However, through the reliability tests, Cronbach Alpha and EFA, the Order Processing Management construct failed. It only remained with five variables. The null hypothesis was that each of these variables has a positive effect on SC performance.

From the results, in model 1, it could be seen that four out of the independent variables had a positive effect on SC performance and they are Demand Management (DM), Customer Relationship Management (CRM), Service Performance Management (SPM) and information and Technology (ITM). However, only Customer Relationship Management (CRM) and Information and Technology (ITM) were significant factors. It was also realized that Capacity Resource Management (CaRM) rather had a negative effect on SC performance, but also not significant. Even though other moderated variables had either positive or negative effect on SC performance; they are all not significant at 0.01 or 0.05 levels.

Therefore, it can be summarized that even though SCM practices has an impact on SC performance; the effect is not much influenced by value creation. However, when each of the SCM practices was moderated with value creation, different results were obtained. It was found out that only one moderated variable had a significant negative effect on SC performance, and that was Information and Technology Management moderated by value creation. Value creation on its own has a strong positive effect on SC performance and it is significant at 0.01 or 0.05 levels. With a $\beta=0.568$; $t=5.316$, it implies that there is about $53 \%$ improvement in supply chain performance when one value is created. However, value creation does not perfectly moderate supply chain management practices. It only moderates with information and technology management to contribute a negative effect on supply chain performance. This means that value creation influences information and technology management to significantly contribute negatively on supply chain performance by about $26 \%$ $(\beta=-0.26 ; t=-2.226)$.

\section{DISCUSSIONS}

The study sought to investigate the impact of value creation on SC practices and performance in manufacturing companies in Ghana. The paper adopted six out of the seven dimensions (factors) of service SCM developed by Ellram et al. (2004). Among the five (5) items that measured Demand Management (DM), all measured mean values fell above 4.0 which showed absolute agreement; indicating that DM is highly adopted as a SC practice among manufacturing firms in Ghana. Similarly, among the eight (8) items that measured Capacity and Resource Management (CaRM), only one item measured a mean value of less than 4.0. This shows that CaRM is highly adopted as a SC practice among manufacturing firms in the study area. Other practices including Service Capacity Management, Order Processing Management, Information and Technology and Customer Relationship Management had similar results as almost all the constructs had mean values of more than 4.0, which exceed the average, implying absolute agreement. Further, the study adopted nine factors of customer value initially developed by Shamah (2012). Nine (9) items were used to measure Value Creation (VC) using a 7-point Likert Scale. Among the nine (9) items, all had mean values of more than 5.0 implying that value creation is really regarded as an important issue by manufacturing firms. These results are consistent with the extant literature that affirms that value creation relies on three parties: customers, employees and investors (O'Malley, 1998) and that supply chains are value creation networks composed of people, technology and organizations (Maglio et al., 2006).

Regarding the measurement of supply chain performance, the study adopted Chen and Paulraj's (2011), ten (10) measurement criteria of supply chain performance (SCP), which gave 
mean values of more than 5.0 implying that manufacturing firms in have measures in place relevant in ensuring supply chain performance. In checking for reliability of the measures, Cronbach Alpha was used to verify the internal consistency among the measures. Also, exploratory factor analysis (EFA) was used to determine convergent validity where some constructs and items were removed and others retained. The correlation results revealed that players in the manufacturing sector partly attribute their supply chain performance to their supply chain practices and value creation. Also, all the supply chain practices had positive correlations with supply chain performance and they were significant at 0.01 or 0.05 levels except Capacity and Resource Management. However, the relationships are not strong since most of the coefficients ( $\mathrm{r}$ ) are less than 0.5. But, correlation between value creation and supply chain performance was positive and quite high (0.528) and significant at 0.05 . From the results, it could be seen that four out of the independent variables had a positive effect on supply chain performance. These are Demand Management (DM), Customer Relationship Management (CRM), Service Performance Management (SPM) and information and Technology (ITM). However, only customer relationship management (CRM) and information and Technology (ITM) were significant factors. It was also realized that Capacity Resource Management had a negative effect on supply chain performance. Even though other moderated variables had either positive or negative effect on supply chain performance, they are all not significant at 0.01 or 0.05 levels. Therefore, it can be summarized that even though supply chain management practices has an impact on supply chain performance, the effect is not much influenced by value creation.

\section{CONCLUSION}

A thorough review of SCM literature indicates that improving competitive advantage and organizational performance is one of the main objectives of SCM practices. The main purpose of the study is to investigate strategic SCM practices that ensure supply chain performance in the manufacturing firms in the Kumasi Metropolis of Ghana; examine the value creation process and factors in the supply chain of manufacturing firms and to determine the effect of value creation on strategic SCM to enhance supply chain performance. Using purposive sampling technique, a sample of hundred (100) respondents were used to collect data for the study. The findings revealed that the manufacturing industry employs SCM practices in their operations. Also, value creation is really an important issue for manufacturing firms. The study concludes that although SCM practices have an impact on supply chain performance, the effect is not much influenced by value creation. It is therefore necessary for actors in the manufacturing industries to identify key SCM practices, which greatly impact on SC performance so as to benefit from their deployment.

\section{References}

Abdallah, A. B., Obeidat, B. Y. and Aqqad, N. O. (2014). The Impact of Supply Chain Management Practices on Supply Chain Performance in Jordan: The Moderating Effect of Competitive Intensity. International Business Research, Vol. 7(3), pp. 13 - 27.

Akyuz Arzu, G., \& Erman Erkan, T. (2010). Supply chain performance measurement: a literature review. International Journal of Production Research, 48(17), 5137-5155

Bengtsson, M., Eriksson, J. \& Wincent, J. (2010). "Co-opetition dynamics - an outline for further inquiry”, Competitiveness Review: An International Business Journal Incorporating Journal of Global Competitiveness, 20 (2), pp. 194-214.

Bititci, U. S., Martinez, V., Albores, P., \& Parung, J. (2004). Creating and Managing Value in Collaborative Networks. International Journal of Physical Distribution \& Logistics Management, 34(3/4), 251-268. http://doi.org/10.1108/09600030410533574

Christiansen, B. (2015). Handbook of Research on Global Supply Chain Management (Vol. 12). IGI Global. Retrieved from https://books.google.com/books?id=pgHq CgAAQBAJ\&pgis=1 
Christopher, M., Peck, H., \& Towill, D. R. (2006). A taxonomy for selecting global supply chain strategies. The, 17(2), 277-287. http://doi.org/10.1108/09574090610689998

Drucker, P. (2012). Management Challenges for the 21st Century. Routledge. Retrieved from https://books.google.com/books?id=1YN3kc31nqAC\&pgis=1

Duclos, L. K., Vokurka, R. J., \& Lummus, R. R. (2003). A conceptual model of supply chain flexibility Industrial Management and Data Systems. Retrieved from http://www.scopus.com/inward/record.url?eid=2-s2.00041361831\&partnerID=tZOtx3y1

Ellram, L.M., Tate, W.L., and Billington, C. (2004). Understanding and managing the service supply chain, The Journal of Supply Chain Management, Fall, pp. 17-32.

Feciková, I. (2004). An index method for measurement of customer satisfaction. The TQM Magazine, 16(1), 57-66.

Gale, B., \& Wood, R. C. (1994). Managing customer value: Creating quality and service that customers can see. Simon and Schuster.

Heydari, J., Baradaran Kazemzadeh, R., \& Chaharsooghi, S. K. (2009). A study of lead time variation impact on supply chain performance. International Journal of Advanced Manufacturing Technology, 40(11-12), 1206-1215. http://doi.org/10.1007/s00170-008-1428-2

Jain, V., Wadhwa, S., \& Deshmukh, S. G. (2009). Revisiting information systems to support a dynamic supply chain: issues and perspectives. Production Planning \& Control, 20(1), 17-29.

http://doi.org/10.1080/09537280802608019

Kampstra, R. P., Ashayeri, J., \& Gattorna, J. L. (2006). Realities of supply chain collaboration. International Journal of Logistics Management, 17(3), 312-330. http://doi.org/10.1108/09574090610717509

Kerr, S., \& Ulrich, D. (1995). Creating the boundaryless organization: The radical reconstruction of organization capabilities. Planning Review, 23(5), 41-45. http://doi.org/10.1108/eb054528

Kristensen, J., \& Górecka, M. (2008). EP Serwis Value Creation and Strategic Supply Chain Management: International Business Economics, Aalborg University.

Lamberg, J. A., \& Laurila, J. (2005). Materializing the societal effect: organizational forms and changing patterns of dominance in the paper industry. Organization Studies, 26(12), 1809-1830.

Li, S., Ragu-Nathan, B., Ragu-Nathan, T.S. \& Rao, S.S. (2006). “The impact of supply chain management practices on competitive advantage and organizational performance", OMEGA, Vol. 34 No. 2, pp. 107-24.

Luo, X., Slotegraaf, R. \& Pan, X. (2006). Cross-Functional “Coopetition”: The Simultaneous Role of Cooperation and Competition within Firms, Journal of Marketing, 70, pp. 67-80.

Lydeka, Z. \& Adomavicius, B. (2007). Cooperation among the Competitors in International Cargo Transportation Sector: Key Factors to Success, Engineering Economics, 1 (51), pp. 80-90.

Maglio, P.P., Srinivasan, S., Kreulen, J.T. \& Spohrer, J. (2006). "Service systems, service scientists, SSME, and innovation", Communications of the ACM, Vol. 49 No. 7, pp. 81-6.

Martínez-olvera, C. (2015). Modeling the Supply Chain Management Creation of Value - A Literature Review of Relevant Concepts.

Monczka, R. M., Petersen, K. J., Handfield, R. B., \& Ragatz, G. L. (1998). Success factors in strategic supplier alliances: the buying company perspective. Decision sciences, 29(3), 553-577.

O'Malley, P. (1998). "Value creation and business success", The Systems Thinker, Vol. 9 No. 2.

Padula, G. \& Dagnino, G. (2007). Untangling the Rise of Coopetition, International Studies of Management and Organization, 37 (2), pp. 32-52.

Pallant, J. (2007). SPSS survival manual, 3rd. Edition. McGrath Hill.

Parasuraman, A., (1997). "Reflections on Gaining Competitive Advantage Through Customer Value", Journal of the Academy of Marketing Science.

Park, J., Shin, K., Chang, T., \& Park, J. (2010). "An integrative framework for supplier relationship management", Industrial Management \& Data Systems, Vol. 110 Iss 4 pp. 495- 515

Paulraj, A. (2011). Understanding the relationships between internal resources and capabilities, sustainable supply management and organizational sustainability. Journal of Supply Chain Management, 47(1), 19-37. 
Rust, R. T., Ambler, T., Carpenter, G. S., Kumar, V., \& Srivastava, R. K. (2004). Measuring marketing productivity: Current knowledge and future directions. Journal of marketing, 68(4), 76-89.

Schnetzler, M., Sennheiser, A., \& Schonsleben, P. (2007). A decomposition-based approach for the development of a supply chain strategy. International Journal of Production Economics, 105(1), 21-42.

http://doi.org/10.1016/j.ijpe.2006.02.004

Shamah, R. (2012). "Innovation within green service supply chain for a value creation", International Journal of Management Modeling, Vol. 7 No. 3, pp. 357-74 (special issue on supply chain management).

Sharifi, H., Ismail, H. S., \& Reid, I. (2006). Achieving agility in supply chain through simultaneous "design of" and "design for" supply chain BT - Dispersed Manufacturing Networks. Journal of Manufacturing Technology Management, 17(8), 1078-1098. http://doi.org/10.1108/17410380610707393

Sukati, I., Hamid, A. B., Baharun, R. \& Yusoff, R. M. (2006). The Study of Supply Chain Management Strategy and Practices on Supply Chain Performance. Social and Behavioral Sciences, Vol., pp. 225 - 233.

Tan, G. W., Shaw, M. J., \& Fulkerson, B. (2000). Web-based Supply Chain Management. Information Systems Frontiers, 2(1), 41-55. Retrieved from http://search.proquest. com/ docview/232037158?accountid=12253

Terzi, S., \& Cavalieri, S. (2004). Simulation in the supply chain context: A survey. Computers in Industry. http://doi.org/10.1016/S0166-3615(03)00104-0

Truong, T. H., \& Azadivar, F. (2005). Optimal design methodologies for configuration of supply chains. International Journal of Production Research, 43(11), 2217-2236. http://doi.org/10.1080/00207540500031998

Ulaga, W. (2001). Customer Value in Business Markets. Industrial Marketing Management, 30, 315-319. http://doi.org/10.1016/S0019-8501 (01)00151-1

Woodruff, R. B. (1995). Customer Value : The Next Source for Competitive Advantage. http://doi.org/10.1007/BF02894350

Xi, Y., \& Canhua, K. (2008). Supply Chain Management and Value Creation, 328.

Zhang, X., Huang, G. Q., \& Rungtusanatham, M. J. (2008). Simultaneous configuration of platform products and manufacturing supply chains. International Journal of Production Research, 46(21), 6137-6162.

http://doi.org/10.1080/00207540701324150 